\title{
Alienation Redux: Marxian Perspectives
}

\author{
Marcello Musto
}

\section{The origin of the concept}

Alienation was one of the most important and widely debated themes of the 20th century, and Marx's theorization played a key role in the discussions . Yet, contrary to what one might imagine, the concept itself did not develop in a linear manner, and the publication of previously unknown texts containing Marx's reflections on alienation defined significant moments in the transformation and dissemination of the theory.

The meaning of the term changed several times over the centuries. In theological discourse it referred to the distance between man and God; in social contract theories, to loss of the individual's original liberty; and in English political economy, to the transfer of property ownership. The first systematic philosophical account of alienation was in the work of G.W.F. Hegel (1770-1831), who in The Phenomenology of Spirit (1807) adopted the terms Entäusserung (literally self-externalization or renunciation) and Entfremdung (estrangement) to denote spirit's becoming other than itself in the realm of objectivity. The whole question still featured prominently in the writings of the Hegelian Left, and Ludwig Feuerbach's (1804-1872) theory of religious alienation - that is, of man's projection of his own essence onto an imaginary deity-elaborated in the book The Essence of Christianity (1841), contributed significantly to the development of the concept.

Alienation subsequently disappeared from philosophical reflection, and none of the major thinkers of the second half of the 19th century paid it any great attention. Even Marx rarely used the term in the works published during his lifetime, and it was entirely absent from the Marxism of the Second International (1889-1914). ${ }^{1}$

During this period, however, several thinkers developed concepts that were later associated with alienation. In his Division of Labour (1893) and Suicide (1897), Émile Durkheim (1858-1917) introduced the term 'anomie'to indicate a set of phenomena whereby the norms guaranteeing social cohesion enter into crisis following a major extension of the division of labour. Social trends concomitant with huge changes in the production process also lay at the basis of the thinking of German sociologists: Georg Simmel (1858-1918), in The Philosophy of Money (1900), paid great attention to the dominance of social institutions over individuals and to the growing impersonality of human relations; while Max Weber (1864-1920), in Economy and Society (1922), dwelled on the phenomena of 'bureaucratization' in society and 'rational calculation' in human relations, considering them to be the essence of capitalism. But these authors thought they were describing unstoppable tendencies, and their reflections were often guided by a wish to improve the existing social and political order certainly not to replace it with a different one.

\section{The rediscovery of alienation}

1 In the introduction to Richard Schacht's (1941-...) volume Alienation, Walter Kaufmann (1921-1980) observed that it was even 'scarcely credible that the modern vogue of 'alienation' should derive from such an unpromising beginning', Walter Kaufmann, 'The Inevitability of Alienation', in Richard Schacht, Alienation, Garden City: Doubleday, 1970, p. XVII. 
The rediscovery of the theory of alienation occurred thanks to György Lukács (1885-1971), who in History and Class Consciousness (1923) referred to certain passages in Marx's Capital (1867) - especially the section on 'commodity fetishism' [Der Fetischcharakter der Ware] - and introduced the term 'reification' [Verdinglichung, Versachlichung] to describe the phenomenon whereby labour activity confronts human beings as something objective and independent, dominating them through external autonomous laws. In essence, however, Lukács's theory was still similar to Hegel's, since he conceived of reification as an 'central structural problem'. ${ }^{2}$ Much later, after the appearance of a French translation by Kostas Axelos (1924-2010) and Jacqueline Bois (?) ${ }^{3}$ had given this work a wide resonance among students and left-wing activists, Lukács decided to republish it together with a long self-critical preface (1967), in which he explained that 'History and Class Consciousness follows Hegel in that it too equates alienation with objectification'. ${ }^{4}$

Another author who focused on this theme in the 1920s was Isaak Rubin (1886-1937), whose Essays on Marx's Theory of Value (1928) argued that the theory of commodity fetishism was 'the basis of Marx's entire economic system, and in particular of his theory of value'. ${ }^{5}$ In the view of this Russian author, the reification of social relations was 'a real fact of the commodity-capitalist economy.'6 It involved "materialization' of production relations and not only 'mystification' or illusion. This is one of the characteristics of the economic structure of contemporary society. [...] Fetishism is not only a phenomenon of social consciousness, but of social being. 7 Despite these insights - prescient if we consider the period in which they were written - Rubin's work did not promote a greater familiarity with the theory of alienation. Its reception in the West began only with its translation into English in 1972 and then from English into other languages.

The decisive event that finally revolutionized the diffusion of the concept of alienation was the appearance in 1932 of the Economic and Philosophic Manuscripts of 1844, a previously unpublished text from Marx's youth. It rapidly became one of the most widely translated, circulated and discussed philosophical writings of the 20th century, revealing the central role that Marx had given to the theory of alienation during an important period for the formation of his economic thought: the discovery of political economy. ${ }^{8}$ For, with his category of alienated labour [entfremdete Arbeit], ${ }^{9}$

2 György Lukács, History and Class Consciousness, Cambridge, MA: MIT Press, 1971, p. 83.

${ }^{3}$ György Lukács, Histoire et conscience de classe, Paris: Minuit, 1960.

${ }^{4}$ Lukács, History and Class Consciousness, p. xxiv.

5 Isaak Illich Rubin, Essays on Marx's Theory of Value, Detroit: Black \& Red, 1972, p. 5 .

6 Ibid., p. 28 (trans. modified).

7 Ibid., p. 59.

8 In fact, Marx had already used the concept of alienation before he wrote the Economic and Philosophic Manuscripts of 1844. In one text he published in February 1844, in the Deutsch-Französische Jahrbücher, he wrote: 'it is [...] the task of history, once the other-world of truth has vanished, to establish the truth of this world. It is the immediate task of philosophy, which is in the service of history, to unmask selfestrangement in its unholy forms once the holy form of human self-estrangement has been unmasked. Thus, the criticism of heaven turns into the criticism of earth, the criticism of religion into the criticism of law and the criticism of theology into the criticism of politics.' Karl Marx, 'A Contribution to the Critique of Hegel's Philosophy of Right. Introduction', in Karl Marx, Early Writings, London: Penguin Books, 1992, pp. 244-5. 
Marx not only widened the problem of alienation from the philosophical, religious and political sphere to the economic sphere of material production; he also showed that the economic sphere was essential to understanding and overcoming alienation in the other spheres. ${ }^{10}$ In the Economic and Philosophic Manuscripts of 1844, alienation is presented as the phenomenon through which the labour product confronts labour 'as something alien, as a power independent of the producer'. For Marx,

the alienation [Entäusserung] of the worker in his product means not only that his labor becomes an object, an external existence, but that it exists outside him, independently, as something alien to him, and that it becomes a power on its own confronting him; it means that the life which he has conferred on the object confronts him as something hostile and alien. ${ }^{11}$

Alongside this general definition, Marx listed four ways in which the worker is alienated in bourgeois society: 1) from the product of his labour, which becomes 'an alien object that has power over him'; 2) in his working activity, which he perceives as 'directed against himself', as if it 'does not belong to him'; 12 3) from 'man's species-being', which is transformed into 'a being alien to him'; and 4) from other human beings, and in relation to 'the other man's labour and object of labour.'13

For Marx, in contrast to Hegel, alienation was not coterminous with objectification as such, but rather with a particular phenomenon within a precise form of economy: that is, wage labour and the transformation of labour products into objects standing opposed to producers. The political difference between these two positions is enormous. Whereas Hegel presented alienation as an ontological manifestation of labour, Marx conceived it as characteristic of a particular, capitalist, epoch of production, and thought it would be possible to overcome it through the emancipation of society from private property'. ${ }^{14} \mathrm{He}$ would make similar points in the notebooks containing extracts from James Mill's (1773-1836) Elements of Political Economy (1821):

My work would be a free manifestation of life, hence an enjoyment of life. Presupposing private property, my work is an alienation of life, for I work in order to live, in order to obtain for myself the means of life. My work is not my life. Secondly, the specific nature of my individuality, therefore, would be affirmed in my labour, since the

\footnotetext{
9 In Marx's writings one finds the term Entfremdung as well as Entäusserung. These had different meanings in Hegel, but Marx uses them synonymously. See Marcella D'Abbiero, Alienazione in Hegel. Usi e significati di Entäusserung, Entfremdung Veräusserung, Rome: Edizioni dell'Ateneo, 1970, pp. 25-7.

10 This elaboration matured also thanks to the influence of the thought of Moses Hess. In fact, in the article 'On the Essence of Money' he had argued that religious alienation had its explanation in the economic and social world. Cfr. Moses Hess, On the Essence of Money, Ann Arbor: Charles River Editors, 2011: 'what God is to the theoretical life, money is to the practical life in this inverted world: the externalised [entäussert] capacity of men, their sold-off life-activity', p. 10.

11 Karl Marx, 'Economic and Philosophic Manuscripts of 1844', in Economic and Philosophic Manuscripts of 1844 and the Communist Manifesto, New York: Prometheus Books, 1988, p. 72.

12 Ibid., p. 74.

13 Ibid., p. 78. For an account of Marx's four-part typology of alienation, see Bertell Ollman, Alienation, New York: Cambridge University Press, 1971, pp. 136-52.

14 Marx, 'Economic and Philosophic Manuscripts of 1844', p. 82.
} 
latter would be an affirmation of my individual life. Labour therefore would be true, active property. Presupposing private property, my individuality is alienated to such a degree that this activity is instead hateful to me, a torment, and rather the semblance of an activity. Hence, too, it is only a forced activity and one imposed on me only through an external fortuitous need, not through an inner, essential one. 15

So, even in these fragmentary and sometimes hesitant early writings, Marx always discussed alienation from a historical, not a natural, point of view.

\section{The other conceptions of alienation}

Much time would elapse, however, before a historical, non-ontological, conception of alienation could take hold. In the early 20th century, most authors who addressed the phenomenon considered it a universal as pect of human existence. In Being and Time (1927), for instance, Martin Heidegger (1889-1976) approached it in purely philosophical terms. The category he used for his phenomenology of alienation was 'fallenness' [Verfallen], that is the tendency of Being-There [Dasein] - which in Heidegger's philosophy indicates the ontologically constituted human existence - to lose itself in the inauthenticity and conformism of the surrounding world. For Heidegger, 'fallenness into the world means an absorption in Being-with-one-another, in so far as the latter is guided by idle talk, curiosity, and ambiguity' something truly quite different from the condition of the factory worker, which was at the centre of Marx's theoretical preoccupations. Moreover, Heidegger did not regard this 'fallenness' as a 'bad and deplorable ontical property of which, perhaps, more advanced stages of human culture might be able to rid themselves', but rather as an ontological characteristic, 'an existential mode of Being-in-the-world'. ${ }^{16}$

Herbert Marcuse (1898-1979), who, unlike Heidegger, knew Marx's work well,17 identified alienation with objectification as such, not with its manifestation in capitalist relations of production. In an essay he published in 1933, he argued that 'the burdensome character of labor'18 could not be attributed merely to 'specific conditions in the performance of la bor, to the social-technical structuring of labor', 19 but should be considered as one of its fundamental traits:

15 Karl Marx, 'Comments on James Mill, Éléments d'économie politique', in Karl Marx, Selected Works, London: Lawrence \& Wishart, 1942, p. 100.

16 Martin Heidegger, Being and Time, San Francisco: Harper, 1962, pp. 220-1. In the 1967 preface to his republished History and Class Consciousness, Lukács observed that in Heidegger alienation became a politically innocuous concept that 'sublimated a critique of society into a purely philosophical problem'. Lukács, History and Class Consciousness, p. xxiv. Heidegger also tried to distort the meaning of Marx's concept of alienation: in his Letter on 'Humanism' (1946), he noted approvingly that, 'by experiencing alienation, [Marx] attains an essential dimension of history', Martin Heidegger, 'Letter on Humanism', in Basic Writings, London: Routledge, 1993, p. 243 - a misleading formulation which has no basis in Marx's writings.

17 Appearing immediately after the publication of the 'Economic and Philosophic Manuscripts of 1844', see for example Herbert Marcuse, 'The Foundation of Historical Materialism', in Studies in Critical Philosophy, Beacon Press, Boston, 1972, pp. $1-49$.

18 Herbert Marcuse, 'On the Philosophical Foundation of the Concept of Labor in Economics', Telos 16 (1973), p. 25.

19 Ibid., pp. 16-17. 
in laboring, the laborer is always 'with the thing': whether one stands by a machine, draws technical plans, is concerned with organizational measures, researches scientific problems, instructs people, etc. In his activity he allows himself to be directed by the thing, subjects hims elf and obeys its laws, even when he dominates his object. [...] In each case he is not 'with himself' [...] he is with an 'Other than himself' even when this doing fulfils his own freely assumed life. This externalization and alienation of human existence [...] is ineliminable in principle. ${ }^{20}$

For Marcuse, there was a 'primordial negativity of laboring activity' that belonged to the 'very essence of human existence'. ${ }^{21}$ The critique of alienation therefore became a critique of technology and labour in general, and its supersession was considered possible only in the moment of play, when people could attain a freedom denied them in productive activity: 'In a single toss of a ball, the player achieves an infinitely greater triumph of human freedom over objectification than in the most powerful accomplishment of technical labor.'22

In Eros and Civilization (1955), Marcuse took an equally clear distance from Marx's conception, arguing that human emancipation could be achieved only through the abolition of labour and the affirmation of the libido and play in social relations. He discarded any possibility that a society based on common ownership of the means of production might overcome alienation, on the grounds that labour in general, not only wage labour, was

work for an apparatus which they [the vast majority of the population] do not control, which operates as an independent power to which individuals must submit if they want to live. And it becomes the more alien the more specialized the division of labor becomes. [...] They work [...] in alienation [... in the] absence of gratification [and in] negation of the pleasure principle. ${ }^{23}$

The cardinal norm against which people should rebel was the 'performance principle'imposed by society. For, in Marcuse's eyes:

the conflict between sexuality and civilization unfolds with this development of domination. Under the rule of the performance principle, body and mind are made into instruments of alienated labor; they can function as such instruments only if they renounce the freedom of the libidinal subject-object which the human organis $m$ primarily is and desires. [...] Man exists [...] as an instrument of alienated performance. ${ }^{24}$

Hence, even if material production is organized equitably and rationally, 'it can never be a realm of freedom and gratification [...] It is the sphere outside labor which defines freedom and fulfilment.'25 Marcuse's alternative was to abandon the Promethean myth so dear to Marx and to draw closer to a

20 Marcuse, 'On the Philosophical Foundation of the Concept of Labor in Economics', p. 25.

21 Ibid.

22 Ibid., pp. 14-15.

23 Herbert Marcuse, Eros and Civilization, Boston: Beacon Press, 1966, p. 45.

24 Ibid., pp. 46-7. Georges Friedmann (1902-1977) was of the same view, arguing in The Anatomy of Work, New York: Glencoe Press, 1964, that the overcoming of alienation was possible only after liberation from work.

25 Marcuse, Eros and Civilization, p. 156. 
Dionysian perspective: the 'liberation of eros'.26 In contrast to Sigmund Freud (1856-1939), who had maintained in Civilization and Its Discontents (1929) that a non-repressive organization of society would entail a dangerous regression from the level of civilization attained in human relations, ${ }^{27}$ Marcuse was convinced that, if the liberation of the instincts took place in a technologically advanced 'free society'28 in the service of humanity, it would not only favour the march of progress but create "new and durable work relations'.29

In this evolution of his thinking, a significant influence was exerted by the ideas of Charles Fourier (1772-1837) who, in his Theory of the Four Movements (1808), opposed advocates of the 'commercial system', to whom he used in a derogatory way the epithet of 'civilized people', and maintained that society would be free only when all its components had returned to expressing their passions. These were far more important to him than reason, in the name of which were perpetrated all the massacres that history remembers'. ${ }^{30}$ According to Fourier, the main error of the political regime of his age was the repression of human nature. 'Harmony' would only be possible only if the individuals could have unleashed, as when they were in their natural state, all theirinstincts .

As for Marcuse, and his belief to oppose the technological domain in general, his indications about how the new society might come about were rather vague and utopian. He ended up opposing technological domination in general, so that his critique of alienation was no longer directed against capitalist relations of production, and his reflections on social change were so pessimistic as to include the working class among the subjects that operated in defence of the system.

The two leading figures in the Frankfurt School, Max Horkheimer (1895-1973) and Theodor Adorno (1903-1965), also developed a theory of generalized estrangement resulting from invasive social control and the manipulation of needs by the mass media. In Dialectic of Enlightenment (1944) they argued that 'a technological rationale is the rationale of domination itself. It is the coercive nature of society alienated from itself.' 31 This meant that, in contemporary capitalism, even the sphere of leisure time - free and outside of work - was absorbed into the mechanisms reproducing consensus.

After World War II, the concept of alienation also found its way into psychoanalysis. Those who took it up started from Freud's theory that man is forced to choose between nature and culture, and that, to enjoy the securities of civilization, he must necessarily renounce his impulses. ${ }^{32}$ Some psychologists linked alienation with the psychoses that appeared in certain individuals as a result of this conflict-ridden choice, thereby reducing the whole vast problematic of alienation to a merely subjective phenomenon.

26 Marcuse, Eros and Civilization, p. 155.

27 Sigmund Freud, Civilization and Its Discontents, New York: Norton, 1962.

28 Marcuse, Eros and Civilization, p. 198.

29 Ibid., p. 155. Cf. The evocation of a 'libidinal rationality which is not only compatible with but even promotes progress toward higher forms of civilized freedom', p. 199. On the relationship between technology and progress, see Kostas Axelos, Alienation, Praxis, and Techné in the Thought of Karl Marx, Austin: University of Texas Press, 1976.

30 Charles Fourier, The Theory of the Four Movements, Cambridge: Cambridge University Press, 1996, p. 100.

31 Max Horkheimer, and Theodor W. Adorno, Dialectic of Enlightenment, New York: Seabury Press, 1972, p. 121.

32 See Freud, Civilization and Its Discontents, p. 62. 
The author who dealt most with alienation from within psychoanalysis was Erich Fromm (1900-1980). Unlike most of his colleagues, he never separated its manifestations from the capitalist historical context; indeed, his books The Sane Society (1955) and Marx's Concept of Man (1961) used the concept to try to build a bridge between psychoanalysis and Marxism. Yet Fromm likewise always put the main emphasis on subjectivity, and his concept of alienation, which he summarized as 'a mode of experience in which the individual experiences himself as alien',33 remained too narrowly focused on the individual. Moreover, his account of Marx's concept based itself only on the Economic and Philosophic Manuscripts of 1844 and showed a deep lack of understanding of the specificity and centrality of alienated labour in Marx's thought. This lacuna prevented Fromm from giving due weight to objective alienation (that of the worker in the labour process and in relation to the labour product) and led him to advance positions that appear disingenuous in their neglect of the underlying structural relations.

Marx believed that the working class was the most alienated class. [... $\mathrm{He}$ ] did not foresee the extent to which alienation was to become the fate of the vast majority of people. [...] If anything, the clerk, the salesman, the executive, are even more alienated today than the skilled manual worker. The latter's functioning still depends on the expression of certain personal qualities like skill, reliability, etc., and he is not forced to sell his 'personality', his smile, his opinions in the bargain. 34

One of the principal non-Marxist theories of alienation is that associated with Jean-Paul Sartre (1905-1980) and the French existentialists. Indeed, in the 1940s, marked by the horrors of war and the ensuing crise de conscience, the phenomenon of alienation - partly under the influence of Alexandre Kojève's (1902-1968) neo-Hegelianism ${ }^{35}$ - became a recurrent reference both in philosophy and in narrative literature. Once again, however, the concept is much more generic than in Marx's thought, becoming identified with a diffuse discontent of man in society, a split between human individuality and the world of experience, and an insurmountable condition humaine. The existentialist philosophers did not propose a social origin for alienation, but saw it as inevitably bound up with all 'facticity' (no doubt the failure of the Soviet experience favoured such a view) and human otherness. In 1955, Jean Hippolyte (1907-1968) set out this position in one of the most significant works in this tendency:

[alienation] does not seem to be reducible solely to the concept of the alienation of man under capitalism, as Marx understands it. The latter is only a particular case of a more universal problem of human self-consciousness which, being unable to conceive itself as an

33 Erich Fromm, The Sane Society, New York: Fawcett, 1965, p. 111.

34 Erich Fromm, Marx's Concept of Man, New York: Frederick Ungar, 1961, pp. 56-7. This failure to understand the specific character of alienated labour recurs in his writings on alienation in the 1960s. In an essay published in 1965 he wrote: 'One has to examine the phenomenon of alienation in its relation to narcissism, depression, fanaticism, and idolatry to understand it fully.' 'The Application of Humanist Psychoanalysis to Marx's Theory', in Erich Fromm, (ed.), Socialist Humanism, New York: Doubleday, 1965, p. 221.

35 See Alexandre Kojeve, Introduction to the Reading of Hegel: Lectures on the Phenomenology of Spirit, Ithaca: Cornell University Press, 1980. 
isolated cogito, can only recognize itself in a word which it constructs, in the other selves which it recognizes and by whom it is occasionally disowned. But this manner of self-discovery through the Other, this objectification, is always more or less an alienation, a loss of self and a simultaneous self-discovery. Thus, objectification and alienation are inseparable, and their union is simply the expression of a dialectical tension observed in the very movement of history. 36

Marx helped to develop a critique of human subjugation, basing hims elf on opposition to capitalist relations of production. The existentialists followed an opposite trajectory, trying to absorb those parts of Marx's work that they thought useful for their own approach, in a merely philosophical discussion devoid of a specific historical critique. ${ }^{37}$

\section{The debate on the conception of alienation in Marx's early writings}

The alienation debate that developed in France frequently drew upon Marx's theories. As the Second World War gave way to a sense of profound anguish resulting from the barbarities of Nazism and fascism, the theme of the condition and destiny of the individual in society acquired great prominence. A growing philosophical interest in Marx was apparent everywhere in Europe. Often, however, it referred only to the Economic and Philosophic Manuscripts of 1844; not even the sections of Capital that Lukács had used to construct his theory of reification were taken into consideration. Moreover, some sentences from the Economic and Philosophic Manuscripts of 1844 were taken out of context and transformed into sensational quotes supposedly proving the existence of a radically different 'new Marx', saturated with philosophy and free of the economic determinism that critics attributed to Capital - often without having read it. Again on the basis of the 1844 texts, the French existentialists laid by far the greates t emphasis on the concept of self-alienation [Selbstentfremdung], that is, the alienation of the worker from the human species and from others like himself - a phenomenon that Marx did discuss in his early writings, but always in connection with objective alienation.

The same error appears in a leading figure of post-war political theory, Hannah Arendt (1906-1975). In her The Human Condition (1958), she built her account of Marx's concept of alienation around the Economic and Philosophic Manuscripts of 1844, even then isolating out only one of the types mentioned there by Marx: subjective alienation. This allowed her to claim:

expropriation and world alienation coincide, and the modern age, very much against the intentions of all the actors in the play, began by alienating certain strata of the population from the world. [...] World alienation, and not self-alienation as Marx thought, has been the hallmark of the modern age. 38

Evidence of her scant familiarity with Marx's mature work is the fact that, in conceding that Marx 'was not altogether unaware of the implications of world alienation in capitalist economy', she referred only to a few lines in his very early journalistic piece, 'The Debates on the Wood Theft Laws'(1842), not to

36 Jean Hyppolite, Studies on Marx and Hegel, New York: Basic Books, 1969, p. 88.

37 Cf. István Mészáros, Marx's Theory of Alienation, London: Merlin Press, 1970, p. $241 \mathrm{ff}$.

38 Hannah Arendt, The Human Condition, Chicago: University of Chicago Press, 1958, pp. 253-4. 
the dozens of much more important pages in Capital and the preparatory manuscripts leading up to it. Her surprising conclusion was: 'such occasional considerations play[ed] a minor role in his work, which remained firmly rooted in the modern age's extreme subjectivism'. ${ }^{39}$ Where and how Marx prioritized 'self-alienation' 40 in his analysis of capitalist society remains a mystery that Arendt never elucidated in her writings.

In the 1960s, the theory of alienation in the Economic and Philosophic Manuscripts of 1844 became the major bone of contention in the wider interpretation of Marx's work. It was argued that a sharp distinction should be drawn between an 'early Marx' and a 'mature Marx' - an arbitrary and artificial opposition favoured both by those who preferred the early philosophical work and those for whom the only real Marx was the Marx of Capital (among them Louis Althusser (1918-1980) and the Russian scholars). Whereas the former considered the theory of alienation in the Economic and Philosophic Manuscripts of 1844 to be the most significant part of Marx's social critique, the latter often exhibited a veritable 'phobia of alienation' and tried at first to downplay its relevance; 41 or, when this strategy was no longer possible, the whole theme of alienation was written off as 'a youthful peccadillo, a residue of Hegelianism'42 that Marx later abandoned. Scholars in the first camp retorted that the 1844 manuscripts were written by a man of twenty-six just embarking on his major studies; but those in the second camp still refused to accept the importance of Marx's theory of alienation, even when the publication of new texts made it clear that he never lost interest in it and that it occupied an important position in the main stages of his life's work.

With the passage of time, successive supporters of the two positions engaged in lively debate, offering different answers concerning the 'continuity' of his thought. Were there in fact two distinct thinkers: an early Marx and a mature Marx? Or was there only one Marx, whose convictions remained substantially the same over the decades?

The opposition between these two views became ever sharper. The first, uniting Marxist-Leninist orthodoxy with those in Western Europe and elsewhere who shared its theoretical and political tenets, downplayed or dismissed altogether the importance of Marx's early writings; they presented them as completely superficial in comparison with his later works and, in so doing, advanced a decidedly anti-humanist conception of his thought. ${ }^{43}$ The second view, advocated by a more heterogeneous group of authors, had as its common denominator a rejection of the dogmatism of official Communism and the correlation that its exponents sought to establish between Marx's thought and the politics of the Soviet Union.

A couple of quotations from two major protagonists in the 1960s will do more than any possible commentary to elucidate the terms of the debate. For Althusser:

first of all, any discussion of Marx's Early Works is a political discussion. Need we be reminded that Marx's Early Works [...] were exhumed by Social-Democrats and exploited by them to the detriment

\footnotetext{
39 Hannah Arendt, The Human Condition, p. 254.

40 Ibid., p. 187.

41 The directors of the Institute of Marxism-Leninism in Berlin even managed to exclude the Economic and Philosophic Manuscripts of 1844 from the numbered volumes of the canonical Marx-Engels Werke, relegating them to a supplementary volume with a smaller print run.

42 Adam Schaff, Alienation as a Social Phenomenon, Oxford: Pergamon Press, 1980, p. 100.

43 Cf. David McLellan, Marx, London: Fontana, 1986, p. 80.
} 
of Marxism-Leninism? [...] This is the location of the discussion: the Young Marx. Really at stake in it: Marxism. The terms of the discussion: whether the Young Marx was already and wholly Marx. ${ }^{44}$

Iring Fetscher (1922-2014), on the other hand, wrote that

the early writings of Marx centre so strongly on the liberation of man from every form of exploitation, domination and alienation, that a Soviet reader must have understood these comments as a criticism of his own situation under Stalinist domination. For this reason then, the early writings of Marx were never published in large, cheap editions in Russian. They were considered to be relatively in significant works by the young Hegelian Marx who had not yet developed Marxism. 45

To argue, as so many did, that the theory of alienation in the Economic and Philosophic Manuscripts of 1844 was the central theme of Marx's thought was so obviously wrong that it demonstrated no more than ignorance of his work. ${ }^{46}$ On the other hand, when Marx again became the most frequently discussed and quoted author in world philosophical literature because of his newly published pages on alienation, the silence from the Soviet Union on this whole topic, and on the controversies associated with it, provided a striking example of the instrumental use made of his writings in that country. For the existence of alienation in the Soviet Union and its satellites was dismissed out of hand, 47 and any texts relating to the question were treated with suspicion. As Henri Lefebvre (1901-1991) put it, in Soviet society, alienation could and must no longer be an issue. By order from above, for reasons of State, the concept had to disappear.'48 Therefore, until the 1970s, very few authors in the 'socialist camp' paid any attention to the works in question.

A number of well-known Western authors also played down the complexity of the phenomenon. Lucien Goldmann (1913-1970), for instance, thought it possible to overcome alienation in the social-economic conditions of the time, and in his Dialectical Research (1959) argued that it would disappear, or recede, under the mere impact of planning. 'Reification,' he wrote, 'is in fact a phenomenon closely bound up with the absence of

44 Louis Althusser, For Marx, Harmondsworth: Penguin Books, 1969, pp. 51 and 53. A few years later, in defending his concept of an 'epistemological break' in Marx's work, Althusser insisted that the discussion on the 'Young Marx' was 'in the last resort, political. [...] This is not a debate about philology! To hang on to or to reject these words, to defend them or to destroy them - something real is at stake in these struggles, whose ideological and political character is obvious. It is not too much to say that what is at stake today, behind the argument about words, is Leninism. Not only the recognition of the existence and role of Marxist theory and science, but also the concrete forms of the fusion between the Labour Movement and Marxist theory, and the conception of materialism and the dialectic.' Louis Althusser, Essays in SelfCriticism, London: New Books, 1971, pp. 114-5.

45 Iring Fetscher, Marx and Marxism, New York: Herder and Herder, 1971, p. 314.

46 Cf. Daniel Bell, 'The Rediscovery of Alienation: Some notes along the quest for the historical Marx', Journal of Philosophy 56, no. 24 (1959), pp. 933-52, which concluded: 'while one may be sympathetic to the idea of alienation, it is only further myth-making to read this concept back as the central theme of Marx', p. 935.

47 A notable exception to this attitude was the Polish scholar Adam Schaff (19132006), who in his book Marxism and the Human Individual, New York: McGraw-Hill, 1970, highlighted how the abolition of private ownership of the means of production did not lead to the automatic disappearance of alienation, since even in 'socialist' societies work retained the character of a commodity.

48 Henri Lefebvre, Critique of Everyday Life, London: Verso, 1991, p. 53. 
planning and with production for the market'; Soviet socialis $m$ in the East and Keynesian policies in the West were resulting in the first case in the elimination of reification, and in the second case in its progressive weakening. ${ }^{49}$ History has demonstrated the faultiness of his predictions.

Whatever their academic discipline or political affiliation, interpreters of the Economic and Philosophic Manuscripts of 1844 may be divided into three groups. The first consists of all those who, in counterposing the Paris manuscripts to Capital, stress the theoretical pre-eminence of the former work. A second group attaches little significance in general to the manuscripts, while a third tends toward the thesis that there is a theoretical continuum between them and Capital.

Those who assumed a split between the young' and the 'mature' Marx, argued for the greater theoretical richness of the former, presented the Economic and Philosophic Manuscripts of 1844 as his most valuable text and sharply differentiated it from his later works. In particular, they tended to marginalize Capital often without studying it in any depth - a book altogether more demanding than the twenty odd pages on alienated labour in the Economic and Philosophic Manuscripts of 1844, about which almost all advanced various philosophical cogitations. ${ }^{50}$ In casting Marx's thought as an ethical-humanist doctrine, these authors pursued the political objective of opposing the rigid orthodoxy of 1930s Soviet Marxism and contesting its hegemony within the workers' movement. This theoretical offensive re sulted in something very different, tending to enlarge the potential field of Marxist theory. ${ }^{51}$ Though the formulations were often hazy and generic, Marxism was no longer considered merely as an economic determinist theory and began to exert a greater attraction for large numbers of intellectuals and young people.

This approach began to make headway soon after the publication in 1932 of the Economic and Philosophic Manuscripts of 1844 and continued to win converts until the late 1950s, partly thanks to the explosive effect of a new text so unlike the dominant canon of Marxism. Its main spons ors were a motley group of heterodox Marxists, progressive Christians and existentialist philosophers, ${ }^{52}$ who interpreted Marx's economic writings as a step back from what they saw as the centrality of the human person in his early theories. 53

The second group of interpreters, who regarded the Economic and Philosophic Manuscripts of 1844 as a transitional text of no special significance in the development of Marx's thought. This was the most widely read account in the Soviet Union and its later satellite countries. The failure of the manuscripts to mention the 'dictatorship of the proletariat', together with the presence of themes such as human alienation and the exploitation of labour that highlighted some of the most glaring contradictions of 'actually existing socialism', led to their ostracization at the top of the ruling Communist parties. Not by chance were they excluded from editions of the works of Marx and Engels in various countries of the 'socialist bloc'.

49 Lucien Goldmann, Recherches dialectiques, Paris: Gallimard, 1959, p. 101.

50 The originators of this line of interpretation were Siegfried Landshut (1897-1968) and Jacob Peter Mayer (1903-1992), shortly followed by Henri de Man (1885-1953).

51 See Schaff, Marxism and the Human Individual, op. cit., p. 5.

52 See Robert Tucker, Philosophy and Myth, Cambridge: Cambridge University Press, 1961 , p. 168.

53 After the Second World War, the main figures were Erich Thier (?), Heinrich Popitz (1925-2002) and Jakob Hommes (1898-1966) in Germany and - although they did not clearly endorse the claim to superiority of the 1844 manuscripts - Maurice Merleau-Ponty (1908-1961), Pierre Bigo (1906-1997), Jean-Yves Calvez (1927-2010) and Axelos in France, and Fromm in the United States. 
Moreover, many of the authors in question wholly endorsed Vladimir Lenin's (1870-1924) definition of the stages in the development of Marx's thought an approach later canonized by Marxism-Leninism, which, apart from being in many respects theoretically and politically questionable, made it impossible to account for Marx's important work newly published for the first time eight years after the death of the Bolshevik leader.

As the influence of the Althusserian school grew in the 1960s, this reading also became popular in France and elsewhere in Western Europe. But, although its basic tenets are generally attributed to Althusser alone, the seeds were already there in Pierre Naville (1903-1993). He believed that Marxism was a science and that Marx's early works, still imbued with the language and preoccupations of Left Hegelianism, marked a stage prior to the birth of a 'new science' in Capital. ${ }^{4}$ For Althusser, as we have seen, the Economic and Philosophic Manuscripts of 1844 represented the Marx most distant from Marxism.

A philologically unfounded contraposition of Marx's early writings to the critique of political economy is shared by dissident or 'revisionist' Marxists eager to prioritize the former and by orthodox Communists focused on the 'mature Marx'. Between them, they contributed to one of the principal misunderstandings in the history of Marxism: the myth of the Young Marx'.55 This antagonism also gave rise to conflicts about the terminology and fundamental concepts of Marxian theory - for example, historical materialism versus historicism, or exploitation versus alienation.

The third and last group of interpreters of the Economic and Philosophic Manuscripts of 1844 consists of those who, from different political and theoretical standpoints, identified a substantive continuity in Marx's work. ${ }^{56}$ The idea of an essential Marxian continuum, as opposed to a sharp theoretical break that completely discarded all that came before, was the inspiration for some of the best interpretations of the concept of alienation in the Economic and Philosophic Manuscripts of 1844. Even then, however, there were a number of errors of interpretation - most notably, in certain authors, an underestimation of Marx's huge advances of the 1850s and 1860s in the field of political economy. This went together with a diffuse tendency to reconstruct Marx's thought through collections of quotations, without taking any account of the different periods in which the source texts had been written. All too often, the result was an author assembled out of pieces corresponding to the interpreter's particular vision, passing backwards and forwards from Economic and Philosophic Manuscripts of 1844 to Capital, as if Marx's work were a single timeless and undifferentiated text. 57

54 See Henri Lefebvre, Marx, Paris: Presses Universitaires de France, 1972, pp. 24 and 26.

55 Cf. Marcello Musto, 'The Myth of the 'Young Marx' in the Interpretations of the Economic and Philosophic Manuscripts of 1844', Critique 43, no. 2 (2015), pp. 233-60. 56 Going back to Herbert Marcuse (1898-1979) or Lukács in German and Jean Hyppolite (1907-1968) or Maximilien Rubel (1905-1996) in French, this approach became hegemonic in the English-speaking world through the work of Robert Tucker (1918-2010), David McLellan (1940-...) and Bertell Ollman (1935-...), then spread to most other parts of the world more widely from the late Sixties on, as the writings of Iring Fetscher (1922-2014), Shlomo Avineri (1933-...), István Mészáros (19302017) and Schaff testify.

57 See the critical points made in this connection by Schaff and Raymond Aron (1905-1983). For the former, 'Marx's texts from the 1840s cannot be quoted indiscriminately alongside those from the 1870 s, as if they carried equal weight for our knowledge of Marxism and had an equal right of abode in our analysis', Schaff, Marxism and the Human Individual, p. 28, trans. modified. For the latter, 'in the years after the war, during the existentialist period, the Jesuit priests Bigo and 
To underline the importance of the concept of alienation in the Economic and Philosophic Manuscripts of 1844 for a better understanding of Marx's development cannot involve drawing a veil of silence over the huge limits of this youthful text. Its author had scarcely begun to as similate the basic concepts of political economy, and his conception of communism was no more than a confused synthesis of the philosophical studies he had undertaken until then. Captivating as they are, especially in the way they combine philosophical ideas of Hegel and Feuerbach with a critique of classical economic theory and a denunciation of working-class alienation, the Economic and Philosophic Manuscripts of 1844 are only a very first approximation, as is evident from their vagueness and eclecticism. They shed major light on the course Marx took, but an enormous distance still separates them from the themes and argument not only of the finished 1867 edition of Capital, Volume I, but also of the preparatory manuscripts for Capital, one of them published, that he drafted from the late 1850s on.

In contrast to analyses that either play up a distinctive 'Young Marx' or try to force a theoretical break in his work, the most incisive readings of the concept of alienation in the Economic and Philosophic Manuscripts of 1844 have known how to treat them as an interesting, but only initial, stage in Marx's critical trajectory. Had he not continued his research but remained with the concepts of the Paris manuscripts, he would probably have been demoted to a place alongside Bruno Bauer (1809-1882) and Feuerbach in the sections of philosophy manuals devoted to the Hegelian Left. 58

\section{The irresistible fascination of the theory of alienation}

In the 1960s a real vogue began for theories of alienation, and hundreds of books and articles were published on it around the world. It was the age of alienation tout court. Authors from various political backgrounds and academic disciplines identified its causes as commodification, overspecialization, anomie, bureaucratization, conformism, consumerism, loss of a sense of self amid new technologies, even personal isolation, apathy, social or ethnic marginalization, and environmental pollution. ${ }^{59}$

The concept of alienation seemed to express the spirit of the age to perfection, and indeed, in its critique of capitalist society, it became a meeting ground for anti-Soviet philosophical Marxism and the most democratic and progressive currents in the Catholic world. However, the popularity of the concept, and its indiscriminate application, created a profound terminological ambiguity. ${ }^{60}$ Within the space of a few years,

Calvez and the existentialists treated the whole of Marxist thought as an atemporal whole, some using texts from 1845, others from 1867, as if Marx's thought did not develop, as if the rough copy of 1844 (not even finished, still less published) contained the best of Marxism', Raymond Aron, D'une Sainte Famille à l'autre, Paris: Éditions Gallimard, 1969, p. 223.

58 Schaff, Marxism and the Human Individual, p. 28.

59 In this context, alienation also became 'an intellectual commodity in the academic market', a very fashionable topic on which to write books and, therefore, an effective and functional tool to make a career in the university world. Cf. David Schweitzer, Fetishization of Alienation. Unpacking a Problem of Science, Knowledge, and Reified Practices in the Workplace, in Alienation, Ethnicity, and Postmodernism, edited by F. Geyer, Westport: Greenwood, 1996, p. 26.

60 Thus Richard Schacht, Alienation, Garden City: Doubleday, 1970, noted that 'there is almost no aspect of contemporary life which has not been discussed in terms of "alienation", p. lix; while Peter C. Ludz, "Alienation as a Concept in the Social Sciences', reprinted in Felix Geyer and David Schweitzer, (eds.), Theories of 
alienation thus became an empty formula ranging right across the spectrum of human unhappiness - so all-encompassing that it generated the belief that it could never be modified.61

With Guy Debord's (1931-1994) book The Society of the Spectacle (1967), which became soon after its publication a veritable manifesto for the generation of students in revolt against the system, alienation theory linked up with the critique of immaterial production. Building on the theses of Horkheimer and Adorno, according to which the manufacturing of consent to the social order had spread to the leisure industry, Debord argued that the sphere of non-labour could no longer be considered separate from productive activity:

Whereas during the primitive stage of capitalist accumulation 'political economy considers the proletarian only as a worker', who only needs to be allotted the indispensable minimum for maintaining his labour power, and never considers him in his leisure and humanity', this ruling-class perspective is revised as soon as commodity abundance reaches a level that requires an additional collaboration from him. Once his workday is over, the worker is suddenly redeemed from the total contempt toward him that is so clearly implied by every aspect of the organization and surveillance of production, and finds himself seemingly treated like a grownup, with a great show of politeness, in his new role as a consumer. At this point the humanism of the commodity takes charge of the worker's 'leisure and humanity' simply because political economy now can and must dominate those spheres. 62

For Debord, then, whereas the domination of the economy over social life initially took the form of a 'degradation of being into having', in the 'present stage' there had been a 'general shift from having to appearing'. ${ }^{63}$ This idea led him to place the world of spectacle at the centre of his analysis: The spectacle's social function is the concrete manufacture of alienation', 64 the phenomenon through which 'the fetishism of the commodity [...] attains its ultimate fulfilment'. 65 In these circumstances, alienation as serted its elf to such a degree that it actually became an exciting experience for individuals, a new opium of the people that led them to consume and 'identify with the dominant images', 66 taking them ever further from their own desires and real existence:

the spectacle is the stage at which the commodity has succeeded in totally colonizing social life. [...] Modern economic production extends its dictatorship both extensively and intensively. [...] With the 'second industrial revolution', alienated consumption has become just as much a duty for the masses as alienated production. 67

Alienation, Leiden: Martinus Nijhoff, 1976, p. 3, remarked that 'the popularity of the concept serves to increase existing terminological ambiguity'.

61 Cf. David Schweitzer, 'Alienation, De-alienation, and Change: A critical overview of current perspectives in philosophy and the social sciences', in Giora Shoham, (ed.), Alienation and Anomie Revisited, Tel Aviv: Ramot, 1982, for whom 'the very meaning of alienation is often diluted to the point of virtual meaninglessness', p. 57.

62 Guy Debord, The Society of the Spectacle, Canberra: Hobgoblin 2002, p. 13.

63 Ibid., p. 9.

64 Ibid., p. 11.

65 Ibid., p. 12.

66 Ibid., p. 11.

67 Debord, The Society of the Spectacle, p. 13. 
In the wake of Debord, Jean Baudrillard (1929-2007) has also used the concept of alienation to interpret critically the social changes that have appeared with mature capitalism. In The Consumer Society (1970), distancing himself from the Marxist focus on the centrality of production, he identified consumption as the primary factor in modern society. The 'age of consumption', in which advertising and opinion polls create spurious needs and mass consensus, was also 'the age of radical alienation'.

Commodity logic has become generalized and today governs not only labour processes and material products, but the whole of culture, sexuality, and human relations, including even fantasies and individual drives. [...] Everything is spectacularized or, in other words, evoked, provoked and orchestrated into images, signs, consumable models. 68

Baudrillard's political conclusions, however, were rather confused and pessimistic. Faced with social ferment on a mass scale, he thought the rebels of May 1968' had fallen into the trap of 'reifying objects and consumption excessively by according them diabolic value'; and he criticized 'all the disquisitions on 'alienation', and all the derisive force of pop and antiart' as a mere 'indictment [that] is part of the game: it is the critical mirage, the anti-fable which rounds off the fable'.69 Now a long way from Marxism, for which the working class is the social reference point for changing the world, he ended his book with a messianic appeal, as generic as it was ephemeral: 'We shall await the violent irruptions and sudden disintegrations which will come, just as unforeseeably and as certainly as May 1968, to wreck this white Mass.'70

\section{Alienation theory in North American sociology}

In the 1950 s, the concept of alienation also entered the vocabulary of North American sociology, but the approach to the subject there was quite different from the one prevailing in Europe at the time. Mainstream sociology treated alienation as a problem of the individual human being, not of social relations, 71 and the search for solutions centred on the capacity of individuals to adjust to the existing order, not on collective practices to change society. ${ }^{72}$

Here, too, there was a long period of uncertainty before a clear and shared definition took shape. Some authors considered alienation to be a positive phenomenon, a means of expressing creativity, which was in herent in the human condition in general.73 Another common view was that it sprang from the fissure between individual and society; ${ }^{74}$ Seymour Melman (1917-2004), for instance, traced alienation to the split between the formulation and execution of decisions, and considered that it affected

68 Jean Baudrillard, The Consumer Society, London: Sage, 1998, p. 191.

69 Ibid., pp. 195-6.

70 Ibid., p. 196.

71 See for example John Clark, 'Measuring alienation within a social system', American Sociological Review 24, no. 6 (1959), pp. 849-52.

72 See Schweitzer, 'Alienation, De-alienation, and Change', pp. 36-7.

73 A good example of this position is Walter Kaufman's 'The Inevitability of Alienation', his introduction to Schacht's previously quoted volume, Alienation. For Kaufman, 'life without estrangement is scarcely worth living; what matters is to increase men's capacity to cope with alienation', p. lvi.

${ }^{74}$ Schacht, Alienation, p. 155. 
workers and managers alike. ${ }^{75}$ In 'A Measure of Alienation' (1957), which inaugurated a debate on the concept in the American Sociological Review, Gwynn Nettler (1913-2007) used an opinion survey as a way of trying to establish a definition. But, in sharp contrast to the rigorous labourmovement tradition of investigations into working conditions, his questionnaire seemed to draw its inspiration more from the McCarthyite canons of the time than from those of scientific re search. ${ }^{76}$ For in effect he identified alienation with a rejection of the conservative principles of American society: 'consistent maintenance of unpopular and averse attitudes toward familism, the mass media and mass taste, current events, popular education, conventional religion and the telic view of life, nationalism, and the voting process'. 77

The conceptual narrowness of the American sociological panorama changed after the publication of Melvin Seeman's (1918-2020) short article 'On the Meaning of Alienation' (1959), which soon became an obligatory reference for all scholars in the field. His list of the five main types of alienation - powerlessness, meaninglessness (that is, the inability to understand the events in which one is inserted), normlessness, isolation and self-estrangement 78 - showed that he too approached the phenomenon in a primarily subjective perspective.

Robert Blauner (1929-2016), in his book Alienation and Freedom (1964), similarly defined alienation as 'a quality of personal experience which results from specific kinds of social arrangements',79 even if his copious research led him to trace its causes to 'employment in the large-scale organizations and impersonal bureaucracies that pervade all industrial societies'. 80

American sociology, then, generally saw alienation as a problem linked to the system of industrial production, whether capitalist or socialist, and mainly affecting human consciousness. ${ }^{81}$ This major shift of approach ultimately downgraded, or even excluded, analysis of the historical-social

75 Seymour Melman, Decision-making and Productivity, Oxford: Basil Blackwell, 1958, pp. 18, 165-6.

76 Among the questions that Nettler put to a sample considered susceptible to 'alien orientation' were: 'Do you enjoy TV? What do you think of the new model of American automobiles? Do you read Reader's Digest? [...] Do you like to participate in church activities? Do national spectator-sports (football, baseball) interest you?', 'A Measure of Alienation', American Sociological Review 22, no. 6 (1957), p. 675. He concluded that negative answers were evidence of alienation: 'there seems little doubt that this scale measures a dimension of estrangement from our society.'

77 Ibid., p. 674. To prove his point, Nettler noted that 'to the question, 'Would you just as soon live under another form of government as under our present one?' all responded with some indication of possibility and none with rejection', p. 674. He even went so far as to claim 'that alienation is related to creativity. It is hypothesized that creative scientists and artists $[. .$.$] are alienated individuals [\ldots]$ that alienation is related to altruism [and] that their estrangement leads to criminal behavior', pp. 676-7.

78 Melvin Seeman, 'On the Meaning of Alienation', American Sociological Review 24, no. 6 (1959), pp. 783-91. In 1972 he added a sixth type to the list: 'cultural estrangement'. See Melvin Seeman, 'Alienation and Engagement', in Angus Campbell and Philip E. Converse, (eds.), The Human Meaning of Social Change, New York: Russell Sage, 1972, pp. 467-527.

79 Robert Blauner, Alienation and Freedom, Chicago: University of Chicago Press, 1964 , p. 15.

80 Ibid., p. 3.

81 Cf. Walter R. Heinz, 'Changes in the Methodology of Alienation Research', in Felix Geyer and Walter R. Heinz, Alienation, Society and the Individual, New Brunswick: Transaction, 1992, p. 217. 
factors that determine alienation, producing a kind of hyperpsychologization that treated it not as a social problem but as a pathological symptom of individuals, curable at the individual level.82 Whereas in the Marxist tradition the concept of alienation had contributed to some of the sharpest criticisms of the capitalist mode of production, its institutionalization in the realm of sociology reduced it to a phenomenon of individual maladjustment to social norms. In the same way, the critical dimension that the concept had had in philosophy (even for authors who thought it a horizon that could never be transcended) now gave way to an illusory neutrality. 83

Another effect of this metamorphosis was the theoretical impoverishment of the concept. From a complex phenomenon related to man's work activity and social and intellectual existence, alienation became a partial category divided up in accordance with academic research specializations. ${ }^{84}$ American sociologists argued that this methodological choice enabled them to free the study of alienation from any political connotations and to confer on it scientific objectivity. But, in reality, this apolitical 'turn' had evident ideological implications, since support for the dominant values and social order lay hidden behind the banner of deideologization and value-neutrality. 85

So, the difference between Marxist and American sociological conceptions of alienation was not that the former were political and the latter scientific. Rather, Marxist theorists were bearers of values opposed to the hegemonic ones in American society, whereas the US sociologists upheld the values of the existing social order, skillfully dressed up as eternal values of the human species. ${ }^{86}$ In the American academic context, the concept of alienation underwent a veritable distortion and ended up being used by defenders of the very social classes against which it had for so long been directed. 87

82 See Felix Geyer and David Schweitzer, 'Introduction', in idem, (eds.), Theories of Alienation, pp. xxi-xxii, and Felix Geyer, 'A General Systems Approach to Psychiatric and Sociological De-alienation', in Giora Shoham, (ed.), Alienation and Anomie Revisited, Tel Aviv: Ramot, p. 141.

83 See Geyer and Schweitzer, 'Introduction', pp. xx-xxi.

84 David Schweitzer, 'Fetishization of Alienation: Unpacking a Problem of Science, Knowledge, and Reified Practices in the Workplace', in Felix Geyer, (ed.), Alienation, Ethnicity, and Postmodernism, Westport: Greenwood Press, 1996, p. 23.

85 According to Marcuse, with this choice of field 'sociology renounces its point of view. Society becomes a reality to be studied like any other field of scientific investigation [...], the broader views of philosophical concepts had to be left aside'. In his opinion, moreover, this was a clearly political position, since the acceptance of the principle of the invariability of social laws will educate men to discipline and obedience to the existing social order and will make it easier for them to resign themselves to that order', in Herbert Marcuse, 'Zur Kritik der Soziologie', Die Gesellschaft 8, no. 2 (1931), p. 278.

86 Cf. John Horton, 'The Dehumanization of Anomie and Alienation: a problem in the ideology of sociology', The British Journal of Sociology 15, no. 4 (1964), pp. 292-3, and David Schweitzer, 'Fetishization of Alienation', p. 23.

87 See Horton, 'The Dehumanization of Anomie and Alienation', pp. 283-4. This thesis is proudly championed by Irving Louis Horowitz (1929-2012) in 'The Strange Career of Alienation: how a concept is transformed without permission of its founders', in Felix Geyer (ed.), Alienation, Ethnicity, and Postmodernism, pp. 17-19. According to Horowitz, 'alienation is now part of the tradition in the social sciences rather than social protest. This change came about with a broadening realization that terms like being alienated are no more and no less value-laden than being integrated.' The concept of alienation thus 'became enveloped with notions of the human condition - [...] a positive rather than a negative force. Rather than view 


\section{The concept of alienation in Capital and its preparatory manuscripts}

Marx's own writings played an important role for those seeking to counter this situation. The initial focus on the Economic and Philosophic Manuscripts of 1844 tended to shift after the publication of new texts and with them it was possible to reconstruct the path of his elaboration from the early writings to Capital.

In the second half of the 1840s, Marx no longer made frequent use of the term 'alienation'. The main exceptions were The Holy Family (1845), The German Ideology (1845-46) and the Manifesto of the Communist Party (1848) all jointly authored with Engels.

In Wage-Labour and Capital (1849), a collection of articles based on lectures he gave to the German Workers' League in Brussels in 1847, Marx returned to the theory of alienation. But the term itself did not appear in these texts, because it would have had too abstract a ring for his intended audience. He wrote that wage labour does not enter into the worker's 'own life activity' but represents a 'sacrifice of his life'. Labour-power is a commodity that the worker is forced to sell 'in order to live', and 'the product of his activity, therefore, is not the aim of his activity': 88

And the labourer who for twelve hours long, weaves, spins, bores, turns, builds, shovels, breaks stone, carries hods, and so on-is this twelve hours' weaving, spinning, boring, turning, building, shovelling, stone-breaking, regarded by him as a manifestation of life, as life? Quite the contrary. Life for him begins where this activity ceases, at the table, at the tavern seat, in bed. The twelve hours' work, on the other hand, has no meaning for him as weaving, spinning, boring, and so on, but only as earnings, which enable him to sit down at a table, to take his seat in the tavern, and to lie down in a bed. If the silk-warm's object in spinning were to prolong its existence as caterpillar, it would be a perfect example of a wage-worker. 89

Until the late 1850s there were no more references to the theory of alienation in Marx's work. Following the defeat of the 1848 revolutions, he was forced to go into exile in London; once there, he concentrated all his energies on the study of political economy and, apart from a few short works with a historical theme,90 did not publish another book. When he began to write about economics again, however, in the Foundations of the Critique of Political Economy (1857-58), better known as the Grundrisse, ${ }^{91}$ he more than once used the term 'alienation'. This text recalled in many respects the analyses of the Economic and Philosophic Manuscripts of 1844, although nearly a decade

alienation as framed by 'estrangement' from a human being's essential nature as a result of a cruel set of industrial-capitalist demands, alienation becomes an inalienable right, a source of creative energy for some and an expression of personal eccentricity for others', p. 18.

88 Karl Marx, 'Wage-Labour and Capital', in Wage-Labour and Capital \& Value, Price and Profit, Moscow: Progress Publishers, 1970, p. 19.

89 Ibid.

90 See for example The Eighteenth Brumaire of Louis Bonaparte, Revelations concerning the Communist Trial in Cologne and Revelations of the Diplomatic History of the Eighteenth Century.

${ }^{91}$ For a commentary on this relevant, but complex, text by Marx see Marcello Musto (ed.), Karl Marx's Grundrisse: Foundations of the Critique of Political Economy 150 years Later, London: Routledge, 2008. 
of studies in the British Library had allowed him to make them considerably more profound:

The social character of activity, as well as the social form of the product, and the share of individuals in production here appear as something alien and objective, confronting the individuals, not as their relation to one another, but as their subordination to relations which subsist independently of them and which arise out of collisions between mutually indifferent individuals. The general exchange of activities and products, which has become a vital condition for each individual - their mutual interconnection here appears as something alien to them, autonomous, as a thing. In exchange value, the social connection between persons is transformed into a social relation between things; personal capacity into objective wealth. 92

The account of alienation in the Grundrisse, then, is enriched by a greater understanding of economic categories and by more rigorous social analysis . The link it establishes between alienation and exchange-value is an important aspect of this. And, in one of the most dazzling passages on this phenomenon of modern society, Marx links alienation to the opposition between capital and 'living labour-power':

The objective conditions of living labour appear as separated, independent values opposite living labour capacity as subjective being. [...] The objective conditions of living labour capacity are presupposed as having an existence independent of it, as the objectivity of a subject distinct from living labour capacity and standing independently over against it; the reproduction and realization, i.e. the expansion of these objective conditions, is therefore at the same time their own reproduction and new production as the wealth of an alien subject indifferently and independently standing over against labour capacity. What is reproduced and produced anew is not only the presence of these objective conditions of living labour, but also their presence as independent values, i.e. values belonging to an alien subject, confronting this living labour capacity. The objective conditions of labour attain a subjective existence vis-à-vis living labour capacity capital turns into capitalist. 93

The Grundrisse was not the only text of Marx's maturity to feature an account of alienation. Five years after it was composed, the 'Results of the Immediate Process of Production' - also known as 'Capital, Volume I: Book 1, Chapter VI, unpublished' (1863-64) - brought the economic and political analyses of alienation more closely together. The rule of the capitalist over the worker,' Marx wrote, 'is the rule of things over man, of dead labour over the living, of the product over the producer.'94 In capitalist society, by virtue of the transposition of the social productivity of labour into the material

92 Karl Marx, Grundrisse: Foundations of the Critique of Political Economy, London: Penguin Books, 1993, p. 157. In another passage on alienation we read: 'rob the thing of this social power and you must give it to persons to exercise over persons', p. 158.

93 Ibid., pp. 461-2.

94 Karl Marx, 'Results of the Immediate Process of Production', in Karl Marx, Marx, Capital: A Critique of Political Economy, Volume One, London: Penguin Books, 1990, p. 990. 
attributes of capital',95 there is a veritable 'personification of things and reification of persons', creating the appearance that 'the material conditions of labour are not subject to the worker, but he to them'.96 In reality, he argued:

Capital is not a thing, any more than money is a thing. In capital, as in money, certain specific social relations of production between people appear as relations of things to people, or else certain social relations appear as the natural properties of things in society. Without a class dependent on wages, the moment individuals confront each other as free persons, there can be no production of surplusvalue; without the production of surplus-value there can be no capitalist production, and hence no capital and no capitalist! Capital and wage-labour (it is thus we designate the labour of the worker who sells his own labour-power) only express two aspects of the self-same relationship. Money cannot become capital unless it is exchanged for labour-power, a commodity sold by the worker himself. Conversely, work can only be wage-labour when its own material conditions confront it as autonomous powers, alien property, value existing for itself and maintaining itself, in short as capital. If capital in its material aspects, i.e. in the use-values in which it has its being, must depend for its existence on the material conditions of labour, these material conditions must equally, on the formal side, confront labour as alien, autonomous powers, as value - objectified labour - which treats living labour as a mere means whereby to maintain and increase itself. 97

In the capitalist mode of production, human labour becomes an instrument of the valorization process of capital, which, 'by incorporatingliving labourpower into the material constituents of capital, [...] becomes an animated monster and [...] starts to act as if consumed by love.'98 This mechanism keeps expanding in scale, until co-operation in the production process, scientific discoveries and the deployment of machinery - all of them social processes belonging to the collective-become forces of capital that appear as its natural properties, confronting the workers in the shape of the capitalist order:

The productive forces [...] developed [by] social labour [...] appear as the productive forces of capitalism. [...] Collective unity in cooperation, combination in the division of labour, the use of the forces of nature and the sciences, of the products of labour, as machinery all these confront the individual workers as something alien, objective, ready-made, existing without their intervention, and frequently even hostile to them. They all appear quite simply as the prevailing forms of the instruments of labour. As objects they are independent of the workers whom they dominate. Though the workshop is to a degree the product of the workers'combination, its entire intelligence and will seem to be incorporated in the capitalist or

\footnotetext{
95 Ibid., p. 1058.

96 Ibid., p. 1054.

97 Ibid., pp. 1005-6.

98 Ibid., p. 1007. On Marx's use of this Johann Wolfgang von Goethe's (1749-1832)

Faust metaphor see the insightful considerations of Siebert S. Prawer, Karl Marx and World Literature, Oxford: Oxford University Press, 1978, p. 325.
} 
his understrappers, and the workers find themselves confronted by the functions of the capital that lives in the capitalist. 99

Through this process capital becomes something 'highly mysterious'. 'The conditions of labour pile up in front of the worker as social forces, and they assume a capitalized form.'100

Beginning in the 1960s, the diffusion of 'Capital, Volume I: Book 1, Chapter VI, unpublished' and, above all, of the Grundrisse paved the way for a conception of alienation different from the one then hegemonic in sociology and psychology. It was a conception geared to the overcoming of alienation in practice - to the political action of social movements, parties and trade unions to change the working and living conditions of the working class. The publication of what, after the Economic and Philosophic Manuscripts of 1844 in the 1930s, may be thought of as the 'second generation' of Marx's writings on alienation therefore provided not only a coherent theoretical basis for new studies of alienation, but above all an anti-capitalist ideological platform for the extraordinary political and social movement that exploded in the world during those years. Alienation left the books of philosophers and the lecture halls of universities, took to the streets and the space of workers'struggles, and became a critique of bourgeois society in general.

\section{Commodity fetishism}

One of Marx's best accounts of alienation is contained in the famous section of Capital on 'The Fetishism of the Commodity and Its Secret', where he shows that, in capitalist society, people are dominated by the products they have created 101 . Here, the relations among them appear not 'as direct social relations between persons [...], but rather as material relations between persons and social relations between things'.102 As he famously wrote:

The mysterious character of the commodity-form consists [...] in the fact that the commodity reflects the social characteristics of men's own labour as objective characteristics of the products of labour themselves, as the socio-natural properties of these things. Hence it also reflects the social relation of the producers to the sum total of labour as a social relation between objects, a relation which exists apart from and outside the producers. Through this substitution, the products of labour become commodities, sensuous things which are at the same time supra-sensible or social. [...] It is nothing but the definite social relation between men themselves which assumes here, for them, the fantastic form of a relation between things. In order, therefore, to find an analogy we must take flight into the misty realm of religion. There the products of the human brain appear as autonomous figures endowed with a life of their own, which enter into relations both with each other and with the human race. So, it is in the world of commodities with the products of men's hands. I call this the fetishism which attaches itself to the products of labour as soon

99 Marx, 'Results of the Immediate Process of Production', p. 1054.

100 Ibid., p. 1056.

101 On the making of Capital see Marcello Musto, Another Marx: Early Manuscripts to the International, London: Bloomsbury, 2018, pp. 137-68. On Marx's magnum opus cf. also the recent Marcello Musto (ed.), Marx's Capital after 150 Years: Critique and Alternative to Capitalism, London: Routledge, 2019.

102 Karl Marx, Capital: A Critique of Political Economy, Volume One, London: Penguin Books, 1990, p. 166. 
as they are produced as commodities, and is therefore inseparable from the production of commodities. ${ }^{103}$

Two elements in this definition mark a clear dividing line between Marx's conception of alienation and the one held by most of the other authors we have been discussing. First, Marx conceives of fetishism not as an individual problem but as a social phenomenon, not as an affair of the mind but as a real power, a particular form of domination, which establishes itself in market economy as a result of the transformation of objects into subjects. For this reason, his analysis of alienation does not confine itself to the disquiet of individual women and men, but extends to the social processes and productive activities underlying it. Second, for Marx fetishism manifests itself in a precise historical reality of production, the reality of wage labour; it is not part of the relation between people and things as such, but rather of the relation between man and a particular kind of objectivity: the commodity form.

As a consequence of this peculiarity of capitalism, individuals had value only as producers, and 'human existence' was subjugated to the act of the 'production of commodities'.104 Hence 'the process of production' had 'mastery over man, instead of being controlled by him'.105 Capital 'care[d] nothing for the length of life of labour power' and attached no importance to improvements in the living conditions of the proletariat. Capital 'attains this objective by shortening the life of labour-power.'106

In bourgeois society, human qualities and relations turn into qualities and relations among things. This theory of what Lukács would call reification illustrated alienation from the point of view of human relations, while the concept of fetishism treated it in relation to commodities. Pace those who deny that a theory of alienation is present in Marx's mature work, we should stress that commodity fetishism did not replace alienation but was only one aspect of it. 107

The theoretical advance from the Economic and Philosophic Manuscripts of 1844 to Capital and its related materials does not, however, consist only in the greater precision of his account of alienation. There is also a reformulation of the measures that Marx considers necessary for it to be overcome. Whereas in 1844 he had argued that human beings would eliminate alienation by abolishing private production and the division of labour, the path to a society free of alienation was much more complicated in Capitaland its preparatory manuscripts.

Marx held that capitalism was a system in which the workers were subject to capital and the conditions it imposed. Nevertheless, it had created the foundations for a more advanced society, and by generalizing its benefits humanity would be able to progress along the faster road of social development that it had opened up. One of Marx's most analytic accounts of the positive effects of capitalist production is to be found towards the end of Capital, Volume I, in the section entitled 'Historical Tendency of Capitalist Accumulation'. In the passage in question, he summarizes the six conditions generated by capitalism - particularly by its centralization - that constitute the basic prerequisites for the birth of communist society. These are: 1) the cooperative labour process; 2) the scientific-technological contribution to production; 3) appropriation of the forces of nature by production; 4)

103 Marx, Capital: A Critique of Political Economy, Volume One, pp. 164-5.

104 Ibid., p. 172.

105 Ibid., p. 175.

106 Ibid. p. 376.

107 Cf. Schaff, Alienation as a Social Phenomenon, p. 81. 
creation of machinery that workers can only operate in common; 5) the economizing of all means of production; and 6) the tendency to the creation of the world market. For Marx:

Hand in hand with this centralization, or this expropriation of many capitalists by a few, other developments take place on an ever-increasing scale, such as the growth of the co-operative form of the labour process, the conscious technical application of science, the planned exploitation of the soil, the transformation of the means of labour into forms in which they can only be used in common, the economizing of all means of production by their use as the means of production of combined, socialized labour, the entanglement of all peoples in the net of the world market, and, with this, the growth of the international character of the capitalist regime. 108

Marx well knew that the concentration of production in the hands of a small number of bosses increased the mass of misery, oppression, slavery, degradation and exploitation'109 for the working class, but he was also aware that the co-operation of wage-labourers is entirely brought about by the capital that employs them.' 110 He was convinced that the extraordinary growth of the productive forces under capitalism, greater and faster than in all previously existing modes of production, had created the conditions to overcome the social-economic relations that capitalism had itself brought about - and therefore to achieve the transition to socialist society.

\section{Communism, emancipation and freedom}

According to Marx, a system that produced an enormous accumulation of wealth for the few and deprivation and exploitation for the general mass of workers must be replaced with an 'association of free men, working with the means of production held in common, and expending their many different forms of labour-power in full self-awareness as one single social labour force.'111 In Capital, Volume I, Marx explained that the 'ruling principle' of this 'higher form of society' would be 'the full and free development of every individual'. ${ }^{112}$ In the Grundrisse he wrote that in communist society production would be 'directly social', 'the offspring of association, which distributes labour internally'. It would be managed by individuals as their 'common wealth'.113 The 'social character of production' [gesellschaftliche Charakter der Produktion] would 'make the product into a communal, general product from the outset'; its associative character would be 'presupposed' and 'the labour of the individual [...] from the outset taken as social labour'.114 As Marx stressed in the Critique of the Gotha Programme (1875), in postcapitalist society individual labour no longer exists in an indirect fashion but directly as a component part of the total labour.'115 In addition, the workers would be able to create the conditions for the eventual

\footnotetext{
108 Marx, Capital: A Critique of Political Economy, Volume One, p. 929.

109 Ibid.

110 Ibid., p. 449.

111 Ibid., p. 171.

112 Ibid., p. 739.

113 Marx, Grundrisse: Foundations of the Critique of Political Economy, p. 158.

114 Ibid., p. 171-2.

115 Karl Marx, Critique of the Gotha Programme, in Marx Engels Collected Works, vol. 24, London: Lawrence \& Wishart, 2010, p. 85.
} 
disappearance of the enslaving subordination of the individual to the division of labour'.116

In Capital, Volume I, Marx highlighted that in communism, the conditions would be created for a form of 'planned cooperation' through which the worker 'strips off the fetters of his individuality and develops the capabilities of his species'.117 In Capital, Volume II (1885), Marx pointed out that society would then be in a position to 'reckon in advance how much labour, means of production and means of subsistence it can spend, without dislocation', unlike in capitalism 'where any kind of social rationality asserts itself only post festum' and 'major disturbances can and must occur constantly'. ${ }^{118}$

This type of production would differ from wage labour because it would place its determining factors under collective governance, take on an immediately general character and convert labour into a truly social activity. This was a conception of society at the opposite pole from Thomas Hobbes's (1588-1679) 'war of all against all'. In referring to so-called free competition, or the seemingly equal positions of workers and capitalists on the market in bourgeois society, Marx stated that the reality was totally differe nt from the human freedom exalted by apologists of capitalism. The system posed a huge obstacle to democracy, and he showed better than anyone else that the workers did not receive an equivalent for what they produced.119 In the Grundrisse, he explained that what was presented as an 'exchange of equivalents' was, in fact, appropriation of the workers' 'labour time without exchange'; the relationship of exchange 'dropped away entirely, or it became a 'mere semblance'. ${ }^{120}$ Relations between persons were 'actuated only by selfinterest'. This 'clash of individuals' had been passed off as the 'the absolute form of existence of free individuality in the sphere of production and exchange'. But for Marx 'nothing could be further from the truth', since 'it is not individuals who are set free by free competition; it is, rather, capital which is set free'. ${ }^{121}$ In the Economic Manuscripts of 1863-67, he denounced the fact that 'surplus labour is initially pocketed, in the name of society, by the capitalist' - the surplus labour that is 'the basis of society's free time' and, by virtue of this, the 'material basis of its whole development and of civilization in general'. ${ }^{122}$ And in Capital, Volume I, he showed that the wealth of the bourgeoisie was possible only by turning the whole lifetime of the worker and his family into labour-time'. ${ }^{123}$

In the Grundrisse, Marx observed that in capitalism 'individuals are subsumed under social production', which 'exists outside them as their fate'. ${ }^{24}$ This happens only through the attribution of exchange-value conferred on the products, whose buying and selling takes place post festum. ${ }^{125}$ Furthermore, 'all social powers of production' - including scientific discoveries, which appear as alien and external to the worker, 126 are posited

116 Ibid., p. 87.

117 Ibid., p. 447.

118 Karl Marx, Capital A Critique of Political Economy, Volume II, London: Penguin, 1992, p. 390.

119 On these questions, see Ellen Meiksins Wood, Democracy against Capitalism, Cambridge University Press, 1995, esp. pp. 1-48.

120 Marx, Grundrisse: Foundations of the Critique of Political Economy, p. 674, 458.

121 Ibid., p. 650.

122 Karl Marx, 'Economic Manuscript of 1861-63', in Marx Engels Collected Works, vol. 30, London: Lawrence \& Wishart, 1988, p. 196.

123 Marx, Capital: A Critique of Political Economy, Volume One, p. 532.

124 Marx, Grundrisse: Foundations of the Critique of Political Economy, p. 158.

125 Ibid., p. 172.

126 Ibid., 585. 
by capital. The very association of the workers, at the places and in the act of production, is 'operated by capital' and is therefore 'only formal'. Use of the goods created by the workers is not mediated by exchange between mutually independent labours or products of labour', but rather 'the social conditions of production within which the individual is active.'127 Marx explained how productive activity in the factory 'concerns only the product of labour, not labour itself', 128 since it 'will occur initially only in a common location, under overseers, regimentation, greater discipline, regularity and the posited dependence in production itself on capital'.129

In order to change these conditions, contrary to the view of many of Marx's socialist contemporaries, a redistribution of consumption goods was not sufficient to reverse this state of affairs. A root-and-branch change in the productive assets of society was necessary. Thus, in the Grundrisse Marx noted that 'the demand that wage labour be continued but capital suspended is self-contradictory, self-dissolving'. ${ }^{130}$ What was required was 'dissolution of the mode of production and form of society based upon exchange value'. ${ }^{131}$ In the address published under the title Value, Price and Profit (1865), he called on workers to 'inscribe on their banner' not 'the conservative motto: 'A fair day's wage for a fair day's work!' [but] the revolutionary watchword: 'Abolition of the wages system!"132

Furthermore, the Critique of the Gotha Programme made the point that in the capitalist mode of production the material conditions of production are in the hands of non-workers in the form of capital and land ownership, while the masses are only owners of the personal condition of production, of labour power'. ${ }^{133}$ Therefore, it was essential to overturn the property relations at the base of the bourgeois mode of production. In the Grundrisse, Marx recalled that the laws of private property - liberty, equality, property property in one's own labour, and free disposition over it - tum into the worker's propertylessness, and the dispossession of his labour, i.e. the fact that he relates to it as alien property and vice versa.' 134 And in 1869, in a report of the General Council of the International Working Men's Association, he asserted that 'private property in the means of production' served to give the bourgeois class the power to live without labour upon other people's labour'. ${ }^{135}$ He repeated this point in another short political text, the Preamble to the Programme of the French Workers' Party (1880), adding that the producers cannot be free unless they are in possession of the means of production' and that the goal of the proletarian struggle must be 'the return of all the means of production to collective ownership'. 136

\footnotetext{
127 Ibid., p. 172.

128 Ibid., p. 586.

129 Ibid., pp. 587.

130 Ibid., p. 308-9.

131 Ibid., p. 264. According to Paul Mattick, Marx and Keynes, Boston: Extending Horizons Books, 1969, 'For Marx, the law of value 'regulates' market capitalism but no other form of social production.' Therefore, he held that 'socialism was, first of all, the end of value production and thus also the end of the capitalist relations of production', p. 362.

132 Karl Marx, 'Value, Price and Profit', in Marx Engels Collected Works, vol. 20, London: Lawrence \& Wishart, 2010, p. 149.

133 Marx, Critique of the Gotha Programme, p. 88.

134 Marx, Grundrisse: Foundations of the Critique of Political Economy, p. 674.

135 Karl Marx, 'Report of the General Council on the Right of Inheritance', in Marx Engels Collected Works, vol. 21, London: Lawrence \& Wishart, 2010, p. 65.

136 Karl Marx, 'Preamble to the Programme of the French Workers' Party', in Marx Engels Collected Works, vol. 24, London: Lawrence \& Wishart, 2010, p. 340.
} 
In Capital, Volume III (1894), Marx observed that when the workers had established a communist mode of production 'private property of the earth by single individuals [would] appear just as absurd as private property of one human being by another'. He directed his most radical critique against the destructive possession inherent in capitalism, insisting that 'even an entire society, a nation, or even all simultaneously existing societies taken together, are not the owners of the earth'. For Marx, human beings were 'simply its possessors, its beneficiaries, and have to bequeath it in an improved state to succeeding generations, as good heads of the household [boni patres familias]'. 137

A different kind of ownership of the means of production would also radically change the life-time of society. In Capital, Volume I, Marx unfolded with complete clarity the reasons why in capitalism the shortening of the working day is [...] by no means what is aimed at in capitalist production, when labour is economized by increasing its productivity'. ${ }^{138}$ The time that the progress of science and technology makes available for individuals is in reality immediately converted into surplus value. The only aim of the dominant class is the 'shortening of the labour-time necessary for the production of a definite quantity of commodities'. Its only purpose in developing the productive forces is the 'shortening of that part of the working day in which the worker must work for himself, and the lengthening [...] the other part [...] in which he is free to work for nothing for the capitalist'. 139 This system differs from slavery or the corvées due to the feudal lord, since 'surplus labour and necessary labour are mingled together'140 and make the reality of exploitation harder to perceive.

In the Grundrisse, Marx showed that 'free time for a few' is possible only because of this surplus labour time of the many. ${ }^{141}$ The bourgeoisie secures growth of its material and cultural capabilities only thanks to the limitation of those of the proletariat. The same happens in the most advanced capitalist countries, to the detriment of those on the periphery of the system. In the Economic Manuscript of 1861-63, Marx emphasized that the 'free development' of the dominant class is 'based on the restriction of development' among the working class'; 'the surplus labour of the workers' is the 'natural basis of the social development of the other section'. The surplus labour time of the workers is not only the pillar supporting the 'material conditions of life' for the bourgeoisie; it also creates the conditions for its 'free time, the sphere of [its] development'. Marx could not have put it better: 'the free time of one section corresponds to the time in thrall to labour of the other section.' 142

For Marx communist society, by contrast, would be characterized by a general reduction in labour time. In the Instructions for the Delegates of the Provisional General Council', composed in August 1866 for the International Working Men's Association ${ }^{143}$, Marx wrote in forthright terms: 'a preliminary condition, without which all further attempts at improvement and emancipation must prove abortive, is the limitation of the working day.' It

137 Karl Marx, Capital: A Critique of Political Economy, Volume Three, London: Penguin Books, 1991, p. 911.

138 Marx, Capital: A Critique of Political Economy, Volume One, p. 437-8.

139 Ibid., p. 438.

140 Ibid., p. 346.

141 Marx, Grundrisse: Foundations of the Critique of Political Economy, p. 708.

142 Marx, 'Economic Manuscript of 1861-63', pp. 192, 191.

143 On the life of the so-called "First International" and on the political role of Marx in this organization see Marcello Musto, 'Introduction', in Marcello Musto (ed.), Workers Unite! The International 150 Years Later, London: Bloomsbury, 2014, pp. 168. 
was needed not only 'to restore the health and physical energies of the working class' but also 'to secure them the possibility of intellectual development, sociable intercourse, social and political action'. ${ }^{144}$ Similarly, in Capital, Volume I, while noting that workers' 'time for education, for intellectual development, for the fulfilling of social functions, for social intercourse, for the free play of the vital forces of his body and his mind' counted as pure 'foolishness' in the eyes of the capitalist class, ${ }^{145}$ Marx implied that these would be the basic elements of the new society. As he put it in the Grundrisse, a reduction in the hours devoted to labour - and not only labour to create surplus value for the capitalist class - would favour the artistic, scientific etc. development of the individuals in the time set free, and with the means created, for all of them'. 146

On the basis of these convictions, Marx identified the 'economy of time, along with the planned distribution of labour time among the various branches of production' as 'first economic law on the basis of communal production'.147 In Theories of Surplus Value (1862-63) he made it even clearer that 'real wealth' was nothing other than 'disposable time'. In communist society, workers' self-management would ensure that 'a gre ater quantity of time' was 'not absorbed in direct productive labour but [...] available for enjoyment, for leisure, thus giving scope for free activity and development'. ${ }^{148}$ In this text, so too in the Grundrisse, Marx quoted a short anonymous pamphlet entitled The Source and Remedy of the National Difficulties, Deduced from Principles of Political Economy, in a Letter to Lord John Russell (1821), whose definition of well-being he fully shared: that is, 'truly wealthy a nation, if there is no interest or if the working day is 6 hours rather than 12'. Wealth is not command over surplus labour time - the real wealth - 'but disposable time, in addition to that employed in immediate production, for every individual and for the whole society.' 149 Elsewhere in the Grundrisse he asked rhetorically: 'what is wealth other than the universality of individual needs, capacities, pleasures, productive forces [...] the absolute working out of his creative potentialities?'150 It is evident, then, that the socialist model in Marx's mind did not involve a state of generalized poverty, but rather the attainment of greater collective wealth.

For Marx, living in a non-alienated society meant building a social organization in which a fundamental value was given to individual freedom. He attached a fundamental value to individual freedom, and his communism was radically different from the levelling of classes envisaged by his various predecessors or pursued by many of his epigones. In the Grundrisse however, he pointed to the foolishness of those socialists (namely the French, who want to depict socialism as the realization of the ideals of bourgeois society articulated by the French revolution) who demonstrate that exchange and exchange value etc. are originally [...] a system of universal freedom and equality, but that they have been perverted by money, capital'. ${ }^{151} \mathrm{He}$ labelled it an 'absurdity' to regard 'free competition is the ultimate development of human freedom'; it was tantamount to a belief that

144 Karl Marx, 'Instructions for the Delegates of the Provisional General Council. The Different Questions', in Marx Engels Collected Works, vol. 20, London: Lawrence \& Wishart, 2010, p. 187.

145 Marx, Marx, Capital: A Critique of Political Economy, Volume One, p. 375.

146 Marx, Grundrisse: Foundations of the Critique of Political Economy, p. 706.

147 Ibid., p. 173.

148 Marx, 'Economic Manuscript of 1861-63', p. 390.

149 Marx, Grundrisse: Foundations of the Critique of Political Economy, p. 397.

150 Ibid., p. 488.

151 Ibid., p. 248. 
'the rule of the bourgeoisie is the terminal point of world history', which he mockingly described as 'middle-class rule is the culmination of world history - certainly an agreeable thought for the parvenus of the day before yesterday'. 152 In the same way, Marx contested the liberal ideology according to which 'the negation of free competition [was] equivalent to the negation of individual freedom and of social production based upon individual freedom'. In bourgeois society, the only possible 'free development' was 'on the limited basis of the domination of capital'. But that 'type of individual freedom' was, at the same time, 'the most sweeping abolition of all individual freedom and the complete subjugation of individuality to social conditions which as sume the form of objective powers, indeed of overpowering objects [...] independent of the individuals relating to one another. ${ }^{153}$ As he wrote in Capital, Volume III:

The realm of freedom really begins only where labour determined by necessity and external expediency ends; it lies by its very nature beyond the sphere of material production proper. Just as the savage must wrestle with nature to satisfy his needs, to maintain and reproduce his life, so must civilized man, and he must do so in all forms of society and under all possible modes of production. This realm of natural necessity expands with his development, because his needs do too; but the productive forces to satisfy these expand at the same time. Freedom, in this sphere, can consist only in this, that socialized man, the associated producers, govern the human metabolism with nature in a rational way, bringing it under their collective control instead of being dominated by it as a blind power; accomplishing it with the least expenditure of energy and in conditions most worthy and appropriate for their human nature. But this always remains a realm of necessity. The true realm of freedom, the development of human powers as an end in itself, begins beyond it, though it can only flourish with this realm of necessity as its basis . The reduction of the working day is the basic prerequisite. ${ }^{154}$

This post-capitalist system of production, together with scientifictechnological progress and a consequent reduction of the working day, creates the possibility for a new social formation in which the coercive, alienated labour imposed by capital and subject to its laws is gradually replaced with conscious, creative activity beyond the yoke of necessity, and in which complete social relations take the place of random, undifferentiated exchange dictated by the laws of commodities and money ${ }^{155}$. It is no longer the realm of freedom for capital but the realm of genuine human freedom.

\section{References}

Althusser, Louis (1969) For Marx, Harmondsworth: Penguin.

152 Ibid., p. 652.

153 Ibid.

${ }^{154}$ Marx, Capital: A Critique of Political Economy, Volume Three, p. 958-9.

155 Cf. Marcello Musto, 'Communism', in Musto (ed.), The Marx Revival: Key Concepts and New Interpretations, Cambridge University Press, 2020, pp. 24-50. 
Althusser, Louis (1971) Essays in Self-Criticism, London: New Books.

Arendt, Hannah (1958) The Human Condition, Chicago: University of Chicago Press.

Aron, Raymond (1969) D’une Sainte Famille à l'autre, Paris: Éditions Gallimard.

Axelos, Kostas (1976) Alienation, Praxis, and Techne in the Thought of Karl Marx, Austin/London: University of Texas Press.

Baudrillard, Jean (1998) The Consumer Society, London: Sage.

Bell, Daniel (1959) 'The Rediscovery of Alienation: Some notes along the quest for the historical Marx', Journal of Philosophy 56, no. 24, pp. 933-952.

Blauner, Robert (1964) Alienation and Freedom, Chicago: University of Chicago Press.

Clark, John (1959) 'Measuring alienation within a social system', American Sociological Review 24, no. 6, pp. 849-852.

D'Abbiero, Marcella (1970) Alienazione in Hegel. Usi e significati di Entaeusserung, Entfremdung, Veraeusserung, Rome: Edizioni dell'Ateneo.

Debord, Guy (2002) The Society of the Spectacle, Canberra: Hobgoblin.

Fetscher, Iring (1971) Marx and Marxism, New York: Herder and Herder.

Fourier, Charles (1996) The Theory of the Four Movements, Cambridge: Cambridge University Press.

Freud, Sigmund (1962) Civilization and its Discontents, New York: Norton.

Friedmann, Georges (1964) The Anatomy of Work, New York: Glencoe Press.

Fromm, Erich (1961) Marx's Concept of Man, New York: Frederick Ungar.

Fromm, Erich (1965a) The Same Society, New York: Fawcett.

Fromm, Erich (ed.) (1965b) The Application of Humanist Psychoanalys is to Marx's Theory', in Erich Fromm (ed.), Socialist Humanism, New York: Doubleday, pp. 228-245.

Geyer, Felix (1982) 'A General Systems Approach to Psychiatric and Sociological De-alienation', in Giora Shoham (ed.), Alienation and Anomie Revisited, Tel Aviv: Ramot, pp. 139-174.

Geyer, Felix and David Schweitzer (eds.) (1976) 'Introduction', in Felix Geyer and David Schweitzer, Theories of Alienation, Leiden: Martinus Nijhoff, pp. xiv-xxv.

Goldmann, Lucien (1959) Recherches dialectiques, Paris: Gallimard. 
Heidegger, Martin (1962) Being and Time, San Francisco: Harper.

Heidegger, Martin (1993) 'Letter on Humanism', in Martin Heidegger, Basic Writings, London: Routledge.

Heinz, Walter R. (1992) 'Changes in the Methodology of Alienation Research', in Felix Geyer and Walter R. Heinz (ed.), Alienation, Society, and the Individual, New Brunswick, NJ: Transaction, pp. 213-221.

Hess, Moses (2011) On the Essence of Money, Ann Arbor: Charles River Editors.

Horkheimer, Max and Theodor W. Adorno (1972) Dialectic of Enlightenment, New York: Seabury Press.

Horowitz, Irving Louis (1996) The Strange Career of Alienation: How a Concept is Transformed Without Permission of its Founders', in Felix Geyer (ed.), Alienation, Ethnicity, and Postmodernism, Westport: Greenwood Press, pp. 17-20.

Horton, John (1964) The Dehumanization of Anomie and Alienation: a problem in the ideology of sociology', The British Journal of Sociology 15, no. 4, pp. 283-300.

Hyppolite, Jean (1969) Studies on Marx and Hegel, New York: Basic Books.

Kaufmann, Walter (1970) 'The Inevitability of Alienation', in Richard Schacht, Alienation, Garden City: Doubleday, pp. xv-lviii.

Kojeve, Alexander (1980) Introduction to the Reading of Hegel: Lectures on the Phenomenology of Spirit, Ithaca: Cornell University Press.

Lefebvre, Henri (1972) Marx, Paris: Presses Universitaires de France.

Lefebvre, Henri (1991) Critique of Everyday Life, London: Verso.

Ludz, Peter C. (1976) 'Alienation as a Concept in the Social Sciences', in Felix Geyer and David Schweitzer (eds.), Theories of Alienation, Leiden: Martinus Nijhoff, pp. 3-37.

Lukacs, Gyorgy (1960) Histoire et conscience de classe, Paris: Minuit.

Lukacs, Gyorgy (1971) History and Class Consciousness, Cambridge: MIT Press.

Mattick, Paul (1969) Marx and Keynes, Boston: Extending Horizons Books.

Marcuse, Herbert (1966) Eros and Civilization, Boston: Beacon Press.

Marcuse, Herbert (1972) 'The Foundation of Historical Materialism', in Studies in Critical Philosophy, Boston: Beacon Press, pp. 1-49.

Marcuse, Herbert (1973) 'On the Philosophical Foundation of the Concept of Labor in Economics', Telos 16, no. 25, pp. 2-37. 
Marcuse, Herbert (1931) 'Zur Kritik der Soziologie', Die Gesellschaft 8, no. 2, p. $270-280$.

Marx, Karl (1942) 'Comments on James Mill, Éléments d'économie politique', in Karl Marx, Selected Works, London: Lawrence \& Wishart, pp. ??-??.

Marx, Karl (1970) 'Wage-Labour and Capital', in Wage-Labour and Capital \& Value, Price and Profit, Moscow: Progress Publishers, pp. 15-48.

Marx, Karl (1988a) 'Economic and Philosophic Manuscripts of 1844', in Economic and Philosophic Manuscripts of 1844 and the Communist Manifesto, New York: Prometheus Books, pp. 13-168.

Marx, Karl (1988b) 'Economic Manuscript of 1861-63', in Marx Engels Collected Works, vol. 30, London: Lawrence \& Wishart, 1988, p. 9451.

Marx, Karl (1990a) 'Results of the Immediate Process of Production', in Kar1 Marx, Marx, Capital: A Critique of Political Economy, Volume One, London: Penguin Books, pp. 943-1084.

Marx, Karl (1990) Capital: A Critique of Political Economy, Volume One, London: Penguin.

Marx, Karl (1991) Capital: A Critique of Political Economy, Volume Three, London: Penguin.

Marx, Karl (1992a) Capital A Critique of Political Economy, Volume Two, London: Penguin.

Marx, Karl (1992b) 'A Contribution to the Critique of Hegel's Philosophy of Right. Introduction', in Karl Marx, Early Writings, London: Penguin, pp. 243-257.

Marx, Karl (1993) Grundrisse: Foundations of the Critique of Political Economy, London: Penguin.

Marx, Karl (2010a) 'Value, Price and Profit', in Marx Engels Collected Works, vol. 20, London: Lawrence \& Wishart, pp. 101-149.

Marx, Karl (2010b) 'Instructions for the Delegates of the Provisional General Council. The Different Questions', in Marx Engels Collected Works, vol. 20, London: Lawrence \& Wishart pp. 185-194.

Marx, Karl (2010c) 'Report of the General Council on the Right of Inheritance', in Marx Engels Collected Works, vol. 21, London: Lawrence \& Wishart, 65-67.

Marx, Karl (2010d) 'Critique of the Gotha Program', in Marx Engels Collected Works, vol. 24, London: Lawrence \& Wishart, 75-99.

Marx, Karl (2010e) 'Preamble to the Programme of the French Workers' Party', in Marx Engels Collected Works, vol. 24, London: Lawrence \& Wishart, 340-342.

McLellan, David (1986) Marx, London: Fontana. 
Meiksins Wood, Ellen (1995) Democracy against Capitalism, Cambridge University Press.

Melman, Seymour (1958) Decision-making and Productivity, Oxford: Basil Blackwell.

Mészáros, István (1970) Marx’s Theory of Alienation, London: Merlin Press.

Musto, Marcello (ed.) (2008) Karl Marx's Grundrisse: Foundations of the Critique of Political Economy 150 years Later, London: Routledge.

Musto, Marcello (2014) 'Introduction', in Marcello Musto (ed.), Workers Unite! The International 150 Years Later, London: Bloomsbury, pp. 1-68.

Musto, Marcello (2015) 'The Myth of the 'Young Marx' in the Interpretations of the Economic and Philosophic Manuscripts of 1844', Critique 43, no. 2, pp. 233-60.

Musto, Marcello (2018) Another Marx: Early Manuscripts to the International, London: Bloomsbury.

Musto, Marcello (2020) 'Communism', in Marcello Musto (ed.), The Marx Revival: Key Concepts and New Interpretations, Cambridge University Press, pp. 24-50.

Musto, Marcello (2019) Marx's Capital after 150 Years: Critique and Alternative to Capitalism, London: Routledge.

Nettler, Gwynn (1957) 'A Measure of Alienation', American Sociological Review22, no. 6, pp. 670-677.

Ollman, Bertell (1971) Alienation, New York: Cambridge University Press.

Prawer, Siebert S. (1978) Karl Marx and World Literature, Oxford: Oxford University Press.

Rubin, Isaak Illich (1972) Essays on Marx's Theory of Value, Detroit: Black $\&$ Red.

Schacht, Richard (1970) Alienation, Garden City: Doubleday.

Schaff, Adam (1970) Marxism and the Human Individual, New York: McGrawHill.

Schaff, Adam (1980) Alienation as a Social Phenomenon, Oxford: Pergamon Press.

Schweitzer, David (1982) 'Alienation, De-alienation, and Change: A critical overview of current perspectives in philosophy and the social sciences', in Giora Shoham (ed.) Alienation and Anomie Revisited, Tel Aviv: Ramot, pp. 27-70.

Schweitzer, David (1996) 'Fetishization of Alienation: Unpacking a Problem of Science, Knowledge, and Reified Practices in the Workplace', in 
Felix Geyer (ed.) Alienation, Ethnicity, and Postmodernism, Westport: Greenwood Press, pp. 21-36.

Seeman, Melvin (1959) 'On the Meaning of Alienation', American Sociological Review 24, no. 6, pp. 783-791.

Seeman, Melvin (1972) 'Alienation and Engagement', in Angus Campbell and Philip E. Converse (eds.), The Meaning of Social Change, New York: Russell Sage, pp. 467-527.

Tucker, Robert (1961) Philosophy and Myth, Cambridge: Cambridge University Press. 